\title{
Are Environmental Contaminants Responsible for 'Globesity'?
}

\author{
Agnieszka Filipiak-Florkiewicz ${ }^{1 *}$, Kinga Topolska ${ }^{1}$, \\ Adam Florkiewicz ${ }^{2}$, Ewa Cieślik ${ }^{1}$ \\ 'Department of Nutrition Technology and Consumption, Faculty of Food Technology, \\ University of Agriculture in Kraków, 30-149 Kraków, \\ Balicka S122, Poland \\ ${ }^{2}$ Department of Food Analysis and Quality Assessment, Faculty of Food Technology, \\ University of Agriculture in Kraków, \\ 30-149 Kraków, Balicka 122, Poland
}

Received: 1 August 2016

Accepted: 28 September 2016

\begin{abstract}
According to the World Health Organization (WHO), worldwide obesity has nearly doubled since 1980. In the previous year 42 million children under the age of 5 were overweight or obese. The concern of governments, the scientific community, and health services is noticed in the causes behind the prevalence of obesity and its prevention. Taking into consideration the reasons underlying obesity, toxic substances found in the environment and the food system have been receiving significant attention. Thus, the aim of this paper was to explore the associations between numerous environmental contaminants (heavy metals, persistent organic pollutants) and obesity. Our hypothesis was that neuroendocrine system disturbances caused by these xenobiotics play a crucial role in the obesity epidemic. The neurotoxicity of these compounds could be connected with the reward center in the brain as well as the endocrine system, and lead to an increase of food intake and, consequently, obesity.

Taking into consideration global health as well as the best interests of society, studies in this area are crucial for understanding this problem.
\end{abstract}

Keywords: obesity, persistent organic pollutants, heavy metals, neuroendocrine system

\section{Introduction}

According to the World Health Organization "an escalating global epidemic of overweight and obesity 'globesity' - is taking over many parts of the world" [1].

*e-mail: a.filipiak-florkiewicz@ur.krakow.pl
Indeed, worldwide obesity is almost twice higher than in 1980 [2], and its prevalence has increased in most countries [3]. The prevalence of obesity has risen substantially in both adults and children, and is recognized as a serious public health problem [4]. However, the escalating trend in the occurrence of this disease in childhood and adolescence is of special concern, not only in industrialized countries, but also in low- and middle-income countries [1]. 
From 1990 to 2010 the global prevalence of overweight and obese children increased, and it is expected to gain over $9 \%$ - which means about 60 million children - by $2020[5]$.

Obesity contributes to several serious health consequences, including cardiovascular disease, type 2 diabetes, musculoskeletal disorders, and some types of cancer [2-3]. Many risk factors are involved in the prevalence of obesity, including a high-calorie diet, a sedentary lifestyle, and a genetic predisposition [6].

Taking into consideration the reasons underlying obesity, toxic substances found in the environment and the food system have been receiving significant attention [4]. Many pollution-related risks to health are particularly high in urban areas and low-income areas, because of higher concentrations of common environmental pollutants excerting high neurological effects, such as cadmium $(\mathrm{Cd})$, lead $(\mathrm{Pb})$, mercury $(\mathrm{Hg})$, arsenic (As), and persistent organic pollutants, i.e., polychlorinated biphenyls (PCBs), hexachlorobenzene (HCB), dichlorodiphenyltrichloroethane (DDT), dichloro diphenyldichloroethylene (DDE), bisphenol A (BPA), and others.

Thus, the belief that obesity is simply a thermodynamic problem of caloric intake and expenditure is being changed by the scientific evidence linking environmental contaminants to obesity [7]. The various chemicals known or presumed to disrupt endocrine systems may also be regarded as important contributors to this disease [8-9].

Moreover, some contaminants can cross the bloodbrain barrier, thus being a neurotoxic threat [10]. It was recently proposed to use the term "environmental obesogens" for those environmental pollutants that disturb endogenous regulation of hormones involved in weight homeostasis [11].

This is why we urgently need a better understanding of which pollutants, if any, can affect the prevalence of obesity [12]. As [7] stated: "The increasing burden of environmental toxins, including persistent organic pollutants and heavy metals, can no longer be ignored as a key etiologic factor in the epidemic of obesity and other diseases."

However, the list of publications concerning this subject is rather short. For example, searching the PubMed database in November 2014 using the keywords "persistent organic pollutants" and "obesity" as well as "heavy metals" and "obesity" gives 31 and 92 records, respectively. The concern of researchers is focused on heavy metals and their neurotoxicity (over 2,500 records). Less is known about the neurotoxic effects of persistent organic pollutants ( 25 records).

The environmental obesogen hypothesis proposes that some perturbations, resulting from exposure to environmental chemicals, may exacerbate the effects of imbalances in diet and exercise, and - as a consequence - lead to an increase in susceptibility to obesity [13]. However, [13] did not describe the effects of heavy metals on the neuroendocrine system in the context of body weight increase. In their review, the authors stated that although there is abundant evidence that environmental factors play an important role in the obesity epidemic, many important questions remain unanswered.

The aim of this paper, therefore, was to explore the associations between persistent organic pollutants, heavy metals, and obesity. We hypothesized that neuroendocrine system disturbances caused by these environmental contaminants (ECs) play a crucial role in this area.

\section{Results and Discussion}

\section{Appetite Control and Eating Behavior - the Neuroendocrine System}

Obesity is associated with abnormal eating behaviors. Today it is known that the reason could be neuroendocrine disturbances [14]. The term "neuroendocrine" can be defined as the communication between the central nervous system (CNS) and endocrine glands (EG), and refers to hormone signaling involving the hypothalamus, pituitary gland, and peripheral body systems [15].

The sensing of neurons in the parabrachial nucleus, thalamus, lateral hypothalamus, orbitofrontal complex, basolateral amygdala, and insular cortex affect such important functions of the brain as the regulation of food intake and body weight, as well as energy balance [16]. The hypothalamus plays a crucial role for the central nervous system regulation of food intake, being a homeostatic control center for many other systems (i.e., reproduction and hormonal balances) [17]. Within the hypothalamus, a rich variety of neurotransmitters and peptide neuromodulators exist, and many of them participate in CNS control of appetite and food intake, food reward, or addiction $[14,18]$.

Among the feeding-stimulatory transmitters (obesogenic action), we should mention catecholamine, norepinephrine, the amino acid gamma-aminobutyric acid (GABA), and three classes of neuropeptides - namely the opioids and the pancreatic polypeptides. The feedinginhibitory neurotransmitters (anorexogenic action) in the brain include the monoamines (in particular dopamine), serotonin (5-hydroxytryptamine, 5-HT), and a long list of gut-brain peptides [18].

Gut hormones seem to communicate information from the gastrointestinal tract to the regulatory appetite centers within the central nervous system via the so-called "gutbrain-axis" [14].

Of special concern among neurotransmitters is dopamine (DA), which seems to regulate food intake by modulating food reward via the mesolimbic circuitry of the brain [19]. Brain imaging studies for the most part, implicate the involvement of DA-modulated reward circuits in pathological eating behaviors [20]. DA, which is synthesized from the amino acid tyrosine, exerts widespread effects both in neuronal (as a neurotransmitter) and non-neuronal tissues (as an autocrine or paracrine agent). The dopamine amount reaches $80 \%$ of total catecholamine levels in mammal brains [21]. There 
are many receptor subtypes of D1 and D2 in the central nervous system; however, both types of dopamine receptors are involved in behavioral, neurobiological, and psychotic disorders. The changes in central dopaminergic transmission affect many aspects of food intake (food selection, satiety, energy expenditure) [22].

There is evidence that food cues increase striatal extracellular DA. Thus, dopamine plays the role in the non-hedonic motivational properties of food [20].

Dopamine is suggested to encode the incentive properties of food. The basis for this notion is that depletion of dopamine or a blockade of dopamine receptors do not diminish pleasurable responses to palatable foods in animals or humans [reviewed by 23].

It has been reported [19] that obese humans have reduced striatal dopamine D2 receptor levels, which is similar to the observations from drug addicts. The deficiency of dopamine may promote compensatory pathological eating to activate reward circuits. The strategies concerned with improving dopamine function may be beneficial for obese patients.

The interactions of neurotransmitters (serotonin, enkephalins, and GABA) that regulate dopaminergic activation of the reward center of the brain - "the brain reward cascade" - has been characterized by [2425]. In the nucleus accumbens, dopamine release is associated with the reinforcement aspects of food. In the hypothalamus, dopamine is associated with the initiation of feeding and the length of feeding. Hormones such as leptin and insulin help to regulate dopamine production [26]. There is evidence that increased leptin signaling specifically in the ventral tegmental area (VTA) decreases food intake and firing rates of DA neurons, while treatments that impair leptin signaling in the VTA increase DA neuronal firing rates, food intake, and the proclivity to ingest highly palatable foods [for review 27]. In healthy people, neurotransmitters work together in a pattern of stimulation or inhibition, the effects spreading downward like a cascade from stimulus input to complex patterns of response leading to feelings of well-being [28]. Any variations within this pathway, whether genetic or environmental (epigenetic), may result in addictive behaviors or Reward Deficiency Syndrome (RDS), which was coined to define addictive behaviors and their genetic components [29-30]. RDS predisposes individuals to high risk for multiple addictive, impulsive, and compulsive behaviors. Depending on genes that control different parts of the reward neurotransmitter pathways, a person may display anything from mild anxiety, irritability, hyperactivity, or risk-taking to compulsive shopping, gambling, and even eating disorders [28]. It is known that serotonergic activation could also influence the function of the dopamine D2 receptor [31].

Serotonin plays an important role in the nervous system, especially regulating appetite, satiety, and mood. In patients with anorexia nervosa, serotonin concentration is decreased [reviewed by 27]. 5-HT acts through several receptors; within the hypothalamus the 5-HT2c receptors are highly expressed. In humans, pharmacologically targeting the serotonin system modulates body weight [33]. However, the mechanism through which 5-HT control food intake is not fully understood, but it is known that there is an inverse relationship between serotonin levels and food intake [34].

The phenomenon of eating without being hungry is postulated to be caused by the rewarding or hedonic properties of (palatable) food, which is one of the reasons for the obesity epidemic [33]. Palatable foods can possibly activate the mesolimbic dopamine (DA) reward system. Hunger and satiety signals from adipose tissue, the pancreas, and the gastrointestinal tract relay the information about energy status through the neural hormonal gut-brain axis [18]. Obese humans express blunted striatal responses to palatable food [23]. A lot of evidence concerning the relationship between diet, dopamine, and obesity have been presented by [35]. This emphasizes that obesity affects not only the present generation but also offspring. The research of [36] has proven that feeding pregnant rats with a highly palatable diet leads to the changes in dopamine and opioid gene expression in reward related to an offspring's brain regions.

Leptin is one of the neurohormones engaged in the regulation of appetite. It is expressed and secreted primarily by adipocytes, and acts via a family of receptor (ob-R) isoforms [37-38]. Because of the fact that this neurohormone is responsible for maintaining body weight (and thus preventing obesity), the disruption of circulating leptin concentrations could have adverse effects. It has been observed that obese individuals have higher leptin levels. Moreover, obesity causes relative leptin resistance in the hypothalamus [39]. The decreased leptin sensitivity in obesity is associated with alterations in varied cellular and molecular processes that attenuate the leptin signal. Therefore, approaches that enhance leptin signaling may be effective in overcoming cellular leptin resistance and combating obesity [40].

According to [41], leptin concentrations in serum increased in the maternal circulation over those in the non-pregnant state, suggesting responsibility not only for appetite suppression but also other physiological roles during gestation. There is evidence that leptin could play a role as a regulator of fetal growth and development during a normal pregnancy [42]. This is why it is crucial to better understand the role of leptin - especially in utero - with respect to metabolic anomalies that are related to the later prevalence of obesity among children and adults [41].

Recent human epidemiological studies have linked the presence of xenobiotic chemicals with increased body mass in humans [43]. Some of them are listed in Table 1. Additionally, there is some evidence that environmental pollutants could modulate the neuroendocrine system. Thus, in our opinion, Grun's and Blumberg's “obesogen hypothesis," which proposes the existence of endocrinedisrupting chemicals with the potential to influence obesity, should be enlarged to "neuroendocrine-disrupting chemicals." 


\section{Environmental Contaminants}

Contaminants such as persistent organic pollutants (POPs) and heavy metals (HMs) could seriously impact the physiological systems of the organism [12]. The biological effects of pollutants may vary between species depending on several factors, including routes of uptake, rates of accumulation, and sensitivity of the target organs [44].

\section{Heavy Metals: Neuroendocrine Disruptions and Obesity}

The sources of heavy metals exposure are contaminated air, food, water, and hazardous occupations. Although the negative impact of heavy metals on human health has been known for a long time, exposure to them continues and is even increasing in some areas [45]. For example, arsenic is common in wood preservatives and mercury is still used in gold mining in many parts of Latin America [45]. In most countries in Africa, mining activities are important sources of heavy metal input to the environment, for example mercury in Algeria and arsenic in Namibia and South Africa [46]. High levels of metal pollution are detected in the Asian and African countries, especially in urban environments [47-48]. Large numbers of people in developing countries depend on all of these activities for their livelihoods. For many of the most polluting and dangerous activities, such as e-waste recycling, the most dependent people are generally the poorest and least-able to cope with the health impacts of lead, cadmium, and other toxins. For example, approximately 80,000 people are employed in lead mining worldwide [49].

At the end of the 20th century, however, emissions of heavy metals started to decrease in developed countries: in the UK, emissions of heavy metals fell by more than $50 \%$ between 1990 and 2000 [45]. There has been a significant and well-documented decrease in blood lead levels (B-Pb) in the developed world [50], mainly because of the phasing out of leaded petrol, but also because of reductions in other sources of lead. Nevertheless, it is highly important to emphasize that whole blood lead levels as low as 1-3 $\mu \mathrm{g} / \mathrm{dl}$ are associated with subclinical neurobehavioral toxicity in young children [51].

Heavy metals occurrence in the air, water, soil, and, in turn, in food could lead to serious health problems caused by short-term (acute effects), but also long-term exposure (chronic effects connected with their accumulation in target organs). Heavy metals mainly enter the human body through two routes - inhalation and ingestion - with ingestion being the main one [52]. Among food products, vegetables could be an abundant source of HMs. It has been proven that almost $50 \%$ of the mean ingestion of lead, cadmium, and mercury through food is due to plant origin [52].

In the last decade, particular attention has been given to the special susceptibility of the fetus and small children to heavy metals during the "critical windows of vulnerability." Because of their special behaviors and dynamic physiology, they may be predisposed to higher environmental exposures and, in turn, harmful effects [53-54]. Epidemiological studies have associated early exposure to $\mathrm{Pb}, \mathrm{Hg}$, $\mathrm{As}$, and $\mathrm{Cd}$ with infant health problems, including neurological, developmental, and endocrine disorders [55]. Heavy metals are very wellestablished neurotoxins, with the potential to interfere with the cellular systems $[12,56]$.

Children are vulnerable to the neurotoxic effects of heavy metal exposure because their brains are still developing. These vulnerabilities are especially prominent during the prenatal period, when there is an immature blood-brain barrier and neuronal growth, migration, and myelination processes occur on a specific and rapid schedule. Moreover, toxic substances can pass through the placental barrier and easily access the developing brain, interfering with these important processes, likely leading to adverse consequences [57]. There is evidence that HMs adversely affect mood. Mercury poisoning is manifested by irritability, poor concentration, memory deficiencies, anxiety, and depression [58-59]. Moreover, lead and manganese have also induced cognitive and behavioral deficits in different population groups with higher exposure levels [60-63]. These metals can differ in their neurological effects, but they both disrupt presynaptic neurotransmission [64].

Methylmercury is a potent neurotoxic chemical. Unborn children (i.e., fetuses) are the most susceptible population group, with exposure being mainly from fish in the diet of the mother [50]. It is important to note that mercury is characterized as a developmental neurotoxicant, indicating its harmful impact on the developing brain in the fetus and child [65]. Human biomonitoring and dietmodelling data indicate that tolerable dietary intakes of methylmercury are exceeded among subpopulations that consume large amounts of fish, e.g., in Scandinavia, North America, and France [50]. However, throughout the developed and developing countries, children face $\mathrm{Hg}$ exposure risks from numerous different sources as well as multiple different species of mercury. This fact is particularly evident in developing nations where children face additional mercury exposure risks via occupational settings (i.e., mining or scavenging), cultural or religious practices (i.e., Ayurveda or Santeria) as well as due to a subsistence diet of fish or marine mammals [65].

Lead poisoning accounts for about $0.6 \%$ of the global burden of disease [51]. It affects many pathways linked to the genesis of depression [66-69]. Higher levels of lead (and also cadmium) were found in individuals with depression, and higher levels of lead in those with schizophrenia [12, 70]. Children are at increased risk of exposure to lead because they are exposed to lead throughout pregnancy and eat more food, drink more water, and breathe more air per unit of body weight [51].

Blood lead levels vary in a wide range from country to country and region to region. The highest blood $\mathrm{Pb}$ concentrations and the largest burden of disease from exposure to lead are seen in low-income countries - in particular in areas where there are industrial uses of lead (such as 
smelters, mines, and refineries). When revised estimates of the burden of disease were made in $2004,16 \%$ of all children worldwide were estimated to have levels above $10 \mu \mathrm{g} / \mathrm{dl}$ [71]. Of children with elevated levels, an estimated 90\% live in low-income regions [51].

The results reported by [72] have evidenced that lead exposure may also influence the risk of obesity. Lead levels in the teeth of children in the United States were positively associated with their Body Mass Index (BMI). It is worth remembering that BMI is not a "gold standard," but only a proxy indicator with the accuracy varying according to the degree of body fat. Thus it may not be a proper tool for assessing weight status at an individual level [73-75]. However, it is, for example, a good indicator of excess adiposity in relatively fat children [73-74]. Despite some drawbacks, it is still the most popular tool used in many studies worldwide.

Physiological differences between children and adults are not only manifest in immature metabolic pathways. Because of the fact that important systems are still differentiating and growing, children have unique susceptibilities not seen in adults - and critical time windows for those susceptibilities. The fetus and infant are especially vulnerable to mercury exposure. The development of the central nervous system is of special interest. Damage to this system caused by mercury is likely to be permanent, and neurotoxic effects can result from prenatal or early postnatal exposure [76]. According to [77], high levels of mercury and $\mathrm{Pb}$ in umbilical cord blood due to prenatal exposure impaired visual processing as shown by visually evoked potential measurement in exposed children after 11 years. Cadmium neurotoxicity is induced via several pathways (including, for example, interference with the blood-brain barrier and induction of apoptosis) [12], which are also involved in the pathophysiology of mood disorders [78]. The list of data describing the effects of $\mathrm{Cd}$ on the central neurotransmitter systems in mammals is rather poor. According to [79], exposure of male mice to $\mathrm{Cd}$ influences various behavioral activities as well as the levels of enzyme activities in the brain tissues of the experimental animals. Cadmium increases DA concentration in the striatum of rats as was shown by [80]. Simultaneously, the decrease of 5-HT level in the brain stem was observed. Similar results have been reported by other researchers [81-84]. Moreover, [41] reported that leptin mRNA decreased dose-responsively as the consequence of $\mathrm{CdCl}_{2}$ exposure. The authors also suggested that this heavy metal may lead to a decline in placental leptin synthesis.

This finding may constitute further evidence of the endocrine-disrupting effect of cadmium, as a constituent of tobacco smoke, on reproduction in women. A study performed by [85] showed that infants born to heavy smokers (more than 20 cigarettes/day) were not only the smallest, but also had cord serum leptin concentrations slightly higher than other studied groups (non-smokers and mothers who smoked less than 20 cigarettes/day). In the authors' opinion, an explanation for these results could be the enhanced steroidogenesis (secondary to chronic hypoxia) leading to an increase in leptin synthesis.

The latent early life-associated regulation model suggests the role of environmental factors in disease etiology [77]. Epidemiologic and toxicological evidence, and over 80 studies in humans and almost 20 animal studies, support a positive association between maternal smoking (cadmium source) and increased risk of overweight/obesity in later life periods [cit. from 86].

According to [87], "the dance of hormones is critical for balancing metabolism." The influence of environmental pollutants on hormone activity is described widely in the book Hormonal Chaos, the Scientific and Social Origins of the Environmental Endocrine Hypothesis [88].

Table 1. Neurotoxic/Obesogenic effects of selected environmental contaminants.

\begin{tabular}{|c|c|c|c|}
\hline Reference & Pollutants & $\begin{array}{c}\text { Studied } \\
\text { model }\end{array}$ & Neurotoxic/obesogenic effects \\
\hline [89] & organochlorine pesticide methoxychlor (Mxc) & $\begin{array}{l}\text { Adult female } \\
\text { CD1 } \\
\text { mice }\end{array}$ & $\begin{array}{l}\text { Mxc exposure caused a dose-related decrease in } \\
\text { striatal levels of dopamine (16-31\%), which were } \\
\text { accompanied by decreased levels of the dopamine } \\
\text { transporter (DAT; } 35-48 \% \text { ) and the vesicular } \\
\text { monoamine transporter } 2 \text { (VMAT2; } 21-44 \% \text { ) }\end{array}$ \\
\hline$[90]$ & $\begin{array}{c}\text { serum dioxin (total } 2005 \text { toxic equivalency [TEQ] } \\
\text { median: } 21.1 \mathrm{pg} / \mathrm{g} \text { lipid) and polychlorinated } \\
\text { biphenyls PCBs ( median sum of PCBs: } 250 \mathrm{ng} / \mathrm{g} \\
\text { lipid) }\end{array}$ & $\begin{array}{l}499 \text { boys } \\
\text { aged } 8 \text { to } 9 \\
\text { years }\end{array}$ & $\begin{array}{l}\text { Boys in the highest exposure quintile of the sum of } \\
\text { dioxin and PCB concentrations and total TEQs had } \\
\text { a significant decrease in mean BMI } z \text { scores of } 0.67 \\
\text { for dioxins and TEQs and } 1.04 \text { for PCBs, com- } \\
\text { pared with boys in the lowest exposure quintile }\end{array}$ \\
\hline [91] & $\begin{array}{l}\text { polychlorinated biphenyls (PCBs), dichlorodiphe- } \\
\text { nyldichloroethylene (DDE), and dichlorodiphen- } \\
\text { yltrichloroethane (DDT) }\end{array}$ & 344 children & $\begin{array}{l}\text { Associations between overweight and PCB and } \\
\text { DDE concentrations were strongest in girls; DDT } \\
\text { was associated with overweight only in boys }\end{array}$ \\
\hline$[92]$ & $\begin{array}{c}\beta \text {-hexachlorocyclohexane }(\beta-\mathrm{HCH}) \text {, Dichloro- } \\
\left.\text { diphenyldichloroethylene ( } \mathrm{p}, \mathrm{p}^{\prime} \mathrm{DDE}\right) \text {, dichlo- } \\
\left.\text { rodiphenyltrichloroethane ( } \mathrm{p}, \mathrm{p}^{\prime} \mathrm{DDT}\right) \text {, dieldrin, } \\
\text { heptachlor epoxide, hexachlorobenzene (HCB), } \\
\text { trans-nonachlor, oxychlordane, and polychlori- } \\
\text { nated biphenyls (PCBs) }\end{array}$ & $\begin{array}{l}1,915 \\
\text { children fol- } \\
\text { lowed until } 7 \\
\text { years of age }\end{array}$ & $\begin{array}{l}\text { In this population with relatively high levels of } \\
\text { exposure to organochlorines, no clear associations } \\
\text { with obesity or BMI emerged }\end{array}$ \\
\hline
\end{tabular}


Table 1. Continued.

\begin{tabular}{|c|c|c|c|}
\hline [93] & $\begin{array}{l}\text { dichlorodiphenyltrichloroethane (DDT) and its } \\
\text { metabolite dichlorodiphenylethylene (DDE) }\end{array}$ & $\begin{array}{l}\text { boys } 9 \text { years } \\
\text { old (in-utero } \\
\text { exposure) }\end{array}$ & $\begin{array}{l}\text { The associations between prenatal exposure to } \\
\text { DDT and DDE and several measures of obesity } \\
\text { were observed }\end{array}$ \\
\hline [94] & $\begin{array}{l}\text { Persistent organic pollutants: i.e. polychlorinated } \\
\text { biphenyl } 138 \text { (PCB138); polychlorinated biphenyl } \\
153 \text { (PCB153); dichlorodiphenyldichloroethylene } \\
\text { (p,p-DDE); hexachlorocyclohexane ( } \beta \text {-HCH) }\end{array}$ & $\begin{array}{l}\text { cohort } 298 \\
\text { adults }\end{array}$ & $\begin{array}{l}\text { PCB } 138 \text { was positively associated with BMI; } \\
\text { HCB, p,p-DDE, and } \beta \text {-HCH showed quadratic as- } \\
\text { sociations with BMI }\end{array}$ \\
\hline [95] & $\begin{array}{l}\text { cadmium,PCBs,dioxins,p,p0-DDE and hexachlo- } \\
\text { robenzene (HCB) }\end{array}$ & $\begin{array}{l}114 \text { children } \\
7-9 \text { years old }\end{array}$ & $\begin{array}{l}\text { Significant negative association was found in girls } \\
\text { between prenatal cadmium exposure and weight, } \\
\text { BMI and waist circumference (indicator of abdom- } \\
\text { inal fat) and the sum of four skin folds (indicator of } \\
\text { subcutaneous fat). In contrast, a significant positive } \\
\text { association (after adjustment for confounders/co- } \\
\text { variates) was found between prenatal, p, p'-DDE } \\
\text { exposure and waist circumference as well as waist/ } \\
\text { height ratio in girls (indicators of abdominal fat). } \\
\text { No significant associations were found for prenatal } \\
\text { PCBs, dioxins, and HCB exposure }\end{array}$ \\
\hline [96] & $\begin{array}{c}\text { 2,2',4,4',5,5'-hexachlorobiphenyl (CB-153) and } \\
\text { 1,1-dichloro-2,2-bis(p-chlorophenyl)ethylene } \\
\text { (p,p'-DDE) }\end{array}$ & $\begin{array}{l}1,109 \\
\text { mother-child } \\
\text { pairs }\end{array}$ & $\begin{array}{c}\text { Study of Greenlandic, Polish, and Ukrainian } \\
\text { populations showed no clear association between } \\
\text { pregnancy and postnatal exposure to p,p'-DDE and } \\
\text { CB-153 and BMI at the age of 5-9 years }\end{array}$ \\
\hline [97] & $\begin{array}{l}\text { polychlorinated biphenyls (PCBs) and p,p'- } \\
\text { dichlorodiphenyldichloroethylene } \\
\text { (DDE) }\end{array}$ & $\begin{array}{l}640 \text { children } \\
\text { at } 5 \text { and } 7-y \\
\text { of age }\end{array}$ & $\begin{array}{c}\text { For 7-year-old girls who had overweight mothers, } \\
\text { PCBs were associated with increased BMI; DDE } \\
\text { was associated with increased waist circumference } \\
\text { (WC) only in girls with overweight mothers. For } \\
\text { boys, no associations were observed }\end{array}$ \\
\hline
\end{tabular}

D1 and D2 dopamine receptors are involved in behavioral, neurobiological, and psychotic disorders, and many of their agonists and antagonists have been used for treating mental disturbances [98].

Iron is essential for the production of neurotransmitters (i.e., 5-HT, DA, and GABA), which is why this metal plays a vital role in the brain [99]. However, excessive intake may have a neurodegenerative effect [100]. $\mathrm{Fe}^{2+}$ can increase oxidation of monoamines such as serotonin and dopamine as reported by [101].

\section{Persistent Organic Pollutants (POPs)}

POPs are characterized by toxicity, slow degradation, lipid solubility, and accumulation in the food chain [102]. Human exposure to these xenobiotics occurs mainly through diet - particularly animal-derived products.

This diverse group of environmental contaminants includes, inter alia, organochlorine pesticides such as dichlorodiphenyltrichloroethane (DDT) and hexachlorobenzene (HCB), polychlorinated biphenyls (PCB), dioxin, perfluorinated compounds such as perfluorooctanoic acid (PFOA) and perfluorooctane sulfonic acid (PFOS), and polybrominated diphenyl ethers (PBDE) [103]. Polychlorinated biphenyls (PCBs) with many industrial and commercial applications are also comprised of POPs [94].

Pesticides represent one of the largest groups of POPs and could have adverse implications for human behavioral disorders, i.e., depression [104], as well as degenerative diseases such as Alzheimer's and Parkinson's [105]. Among proposal mechanisms regarding pesticide neurotoxicity, the inhibition of potassium transport as well as $\mathrm{Na}^{+} / \mathrm{K}^{+}$and $\mathrm{Ca}^{2+} / \mathrm{Mg}^{2+}$ ATPase are considered. The others are the closure of sodium channels and the inhibition of calcium calmodulin binding with neurotransmitter release, which all serve to make neurons hyperexcitable [106]. Pesticides get accumulated in the body and change the gene expression profile in exposed tissues. These contaminants are thus believed to be one such xenobiotic that can alter the regulatory framework and lead to disease onset and progression through epigenetic changes. As suggested by [86], epigenetic mechanisms may serve as the critical biological links between genetic vulnerability, in utero exposure, and the development of metabolic syndrome via the regulation of gene expression (DNA methylation, histone modifications, and chromatin remodeling).

There is evidence that some environmental contaminants disrupt endocrine systems, and may play a role in the obesity epidemic [6,107-108]. Consistent with human findings, the animal study also showed that rats exposed to POPs clearly developed visceral obesity [6].

In the studies of [109] as well as [110], the positive relationship between the concentration of persistent organic pollutants in blood and obesity was observed. This could be due to reason, that adiposity itself slows down the metabolism of these compounds [6]. Moreover, 
the environmental chemicals disturb the metabolism of glucose and lead to the induction of insulin resistance [111]. Among other mechanisms of a toxins' action, we will mention inflammation as well as impairment of central appetite regulation [87, 112]. POPs have been shown to disrupt major weight-controlling hormones [113] and to alter not only levels, but also sensitivity to such neurotransmitters as serotonin, dopamine, and noradrenaline [114]. As [115] observed, maximal dopamine uptake in $\mathrm{C} 57 \mathrm{BL} / 6$ mice treated with permethrin, and also for heptachlor. Simultaneously, the authors reported a significant decrease in calculated maximal rates of serotonin uptake for $12 \mathrm{mg} / \mathrm{kg}$ heptachlor-treated mice.

As a result of all the interferences caused by POPs, several changes related to appetite, food efficiency, and the ability to exercise could be observed [4].

In the 1970s some authors [116-117] reported the obesogenic effect of dieldrin or hexachlorobenzene in experimental animals. Recent studies have also proven that chronic exposure to the herbicide Atrazine or mixed persistent organic pollutants were responsible for visceral obesity, insulin resistance, and dyslipidemia [118119].

According to [4], the differences in the values of body mass index caused by POPs in dependence on gender remain unclear. As an example, oxychlordane is associated with BMI increase in males and decrease in females. Furthermore, DDT led to waist circumference (WC) decrease in males, and an increase in females. Hormonally directed differences in fat storage in men (fat stored in the waist) versus women (fat storage mainly in hips) may be the basis, and this process might be affected by POPs.

As [120] stated, the results of human studies concerning the relationship between persistent organic pollutants and obesity differed significantly by taking into consideration prenatal exposure. In adults, the different impairment in dependence on the kind of POPs was observed. For example, a positive cross-sectional connection between serum level of DDT with adiposity was observed.

Experimental studies have also shown the obesitypromoting effects of dichlorodiphenyltrichloroethane (DDT)/dichlorodiphenyldichloroethylene (DDE). Exposure of adipocytes to DDE increased basal fatty acid uptake over a $24 \mathrm{~h}$ period and significantly increased the release of leptin, resistin, and adiponectin. These results may indicate a DDE-induced obesity-promoting adipocyte dysfunction [121].

PCBs also have had a negative impact on serum leptin levels [122]. The authors found that serum leptin levels appear to be more sensitive to short-term exposure to small amounts of PCBs than serum thyroid hormones. The accumulation of PCBs in adipocytes could lead to the interruption of protein synthesis. Toxins may inhibit satiety effects of leptin, leading to an increase of hunger [87].

The other chemical that should be of special interest is bisphenol A (BPA), used in a wide variety of consumer products (e.g., polycarbonate and other forms of plastics, resins used to line food and beverage containers, thermal print papers). There have been several studies, including epidemiological ones, describing the relationships between total bisphenol A concentration in urine and many serious health problems, including not only the reproductive effects in women and men, but also cardiovascular disease, type 2 diabetes, obesity and - of particular interest - neurobehavioral deficits [123-124]. The increased susceptibility of fetuses and infants to exposure of chemicals such as BPA (taking into consideration, among many factors, the age-related changes occurring in the ability to metabolize BPA) have also been reviewed by [125].

Several chemicals (i.e., bisphenol A, mono-ethylhexyl phthalate, butylparaben, and PCB 153) were studied by [126]. The authors observed the increase of leptin release and concluded that these findings strengthen the hypothesis that chemicals can interfere with pathways related to obesity development. Dioxins are primarily byproducts of industrial activities. One of the best known, and also the most potent, is 2,3,7,8-tetrachlorodibenzodioxin (TCDD). PCBs are endocrine disruptors, because they have the ability to agonize as well as to antagonize the estrogen action [104]. However, most of the studies concerned with exposure to these POPs did not prove the association with the obesity of children, adolescents, or adults. Contrary results were reported only on the basis of one prospective study of among Belgian children that observed a positive correlation between PCBs in umbilical cord levels and body mass index values [72]. Weight-gain effect was also observed in rats [127]. According to [7], rats given toxic chemicals gained weight and increased their fat storage without increasing caloric intake or decreasing exercise, and there is evidence that some POPs are associated with abdominal obesity. As [6] suggested, this could be a reason for their contribution to the obesity epidemic.

Environmental pollutants could be responsible, to some extent, for globesity as described above. It is becoming clear that healthful nutrition intervention might be a powerful tool to reduce the risk of diseases associated with ECs [128]. Many studies indicate the beneficial role of dietary antioxidants such as vitamins $\mathrm{C}$ and $\mathrm{E}, \beta$-carotene, and selenium, as well as antioxidantrich plant extracts (e.g., green tea, blackberry extract) against heavy metals and other environmental pollutants [129-132]. In turn, the dietary intake of curcumin and its use as a nutritional supplement may have a potential for organism protection, inter alia, from cadmium intoxication and neurotransmitters dysfunction in the brain [79]. The n-3 polyunsaturated fatty acids (PUFA) are also dietary factors that have the potential to facilitate a reduction in body fat deposition [133]. They can reverse the dysregulation of the endocannabinoid system, which is just linked to a decrease in insulin resistance and body fat [134]. In the authors opinion this explains observations that certain PCBs can promote obesity as well as how n-3 PUFA can reduce body fat deposition and improve obesity-induced metabolic syndrome. The complex role of PUFA in membrane and signal 
transduction has been related to changes in neurotransmitter physiology, such as dopamine and serotonin. Some animal studies suggest a role of docosahexaenoic acid (n-3 DHA), and also arachidonic acid (n-6 AA) in neurotransmitter synthesis or turnover [135]. On the other hand, concern for environmental contamination with POPs prompts caution in the recommendation for consumption of fish and fish oil [136]. The authors observed significant negative effects of PCBs on oxidative stress and antioxidant capacity in rats, so further studies in this area are needed.

It must be emphasized that human studies are recommended to confirm the protective role of dietary compounds against environmental contaminants. This is particularly important because some studies suggest that the interaction of toxicants and nutrients occurs throughout the body, and that the consequences of tissue damage by environmental pollutants can be significant.

\section{Conclusions}

Obesity is an important risk factor that influences global health. This serious disease is regulated by the CNS. As we described above, persistent organic pollutants as well as heavy metals could impair the organism, via mechanisms similar to those in neurodegenerative diseases, i.e., Parkinson's. Neurotoxicity of these compounds is connected with Dopamine-based reward circuitry as well as the endocrine system, and lead to an increase of food intake and - in consequence - obesity. The problem is even more serious because some authors $[95,137-138]$ stated that exposure to pesticides and other environmental contaminants during the early stages of life could increase vulnerability to such substances in later life periods. According to WHO [139], as evidence grows on the fetal determinants of adult disease, the importance of promoting a healthier environment for pregnant women are recognized as priorities.

Despite our database search not allowing us to find a direct connection between neurotoxicity of persistent organic pollutants and heavy metals and obesity prevalence, we suggest that this association exists. Moreover, it is knowing that obese individuals inhale more pollutants, and that there are higher xenobiotic impairment risks (increased food intake) than normal weighted subjects. Additionally, the harmful side-effect of weight loss by patients with obesity could be an elevated concentration of toxic pollutants in blood [140]. Taking into consideration global health as well as the best interests of society, studies in this area are strongly needed.

\section{Acknowledgements}

The publication of this paper was supported by the Ministry of Science and Higher Education of Poland (in the form of a subsidy for the purpose of maintaining research potential).

\section{References}

1. KELISHADI R., POURSAFA P. Obesity and air pollution: global risk factors for pediatric non-alcoholic fatty liver disease. Hepat. Mon. 11 (10), 794-802, 2011.

2. WEICHENTHAL S., HOPPIN J.A., REEVES F. Obesity and the cardiovascular health effects of fine particulate air pollution. Obesity. 22 (7), 1580, 2014.

3. YACH D., STUCKLER D., BROWNELL K.D. Epidemiologic and economic consequences of the global epidemics of obesity and diabetes. Nature Medicine. 12, 62, 2006.

4. ELOBEID M.A., BROCK D.W., ALLISON D.B., PADILLA M.A., RUDEN D.M. Endocrine Disruptors and Obesity: An Examination of Selected Persistent Organic Pollutants in the NHANES 1999-2002 Data. Int. J. Environ. Res. Public. Health. 7 (7), 2988, 2010.

5. DE ONIS M., BLOSSNER M., BORGHI E. Global prevalence and trends of overweight and obesity among preschool children. Am. J. Clin. Nutr. 92 (5), 1257, 2010.

6. LEE D.H., STEFFES M.W., SJÖDIN A., JONES R.S., NEEDHAM L.L., JACOBS Jr. D.R. Low dose organochlorine pesticides and polychlorinated biphenyls predict obesity, dyslipidemia, and insulin resistance among people free of diabetes. PLoS One. 6 (1), article ID: e15977, 2011.

7. HYMAN M.A. Environmental toxins, obesity, and diabetes: an emerging risk factor. Altern. Ther. Health. Med. 16 (2), $56,2010$.

8. GRÜN F., BLUMBERG B. Endocrine disrupters as obesogens. Mol. Cell. Endocrinol. 304 (1-2), 19, 2009.

9. NEWBOLD R.R., PADILLA-BANKS E., JEFFERSON W.N. Environmental estrogens and obesity. Mol. Cell. Endocrinol. 304 (1-2), 84, 2009.

10. AITLHADJ L., ÁVILA D.S., BENEDETTO A., ASCHNER M., STÜRZENBAUM S.R. Environmental exposure, obesity, and Parkinson's disease: lessons from fat and old worms. Environ. Health. Perspect. 119 (1), 20, 2011

11. LEE D.H. Persistent organic pollutants and obesityrelated metabolic dysfunction: focusing on type 2 diabetes. Epidemiol. Health. 34, article ID: e2012002, 2012.

12. BERK M., WILLIAMS L.J., ANDREAZZA A.C., PASCO J.A., DODD S., JACKA F.N., MOYLAN S., REINER E.J., MAGALHAES P.V.S. Pop, heavy metal and the blues: secondary analysis of persistent organic pollutants (POP), heavy metals and depressive symptoms in the NHANES National Epidemiological Survey. BMJ Open. 4 (7), 1, 2014.

13. GRÜN F., BLUMBERG B. Minireview: The Case for Obesogens. Molr. Endocrinol. 23 (8), 1127, 2009.

14. BUHMANN H., LE ROUX C.W., BUETER M. The gutbrain axis in obesity. Best Pract. Res. Clin. Gastroenterol. 28 (4), 559, 2014

15. MATTERI R.L., CARROLL J.A., DYER C.J. Neuroendocrine Responses to Stress. The Biology of Animal Stress. 2000.

16. MARTINS I.J., CREEGAN R., LIM W.L.F., MARTINS R.N. Molecular Insights into Appetite Control and Neuroendocrine Disease as Risk Factors for Chronic Diseases in Western Countries. OJEMD. 3, 11, 2013.

17. VAN DEN POL A.N. Weighing the role of hypothalamic feeding neurotransmitters. Neuron. 40 (6), 1059, 2003.

18. ZHANG Y., LIU J., YAO J., JI G., QIAN L., WANG J., ZHANG G., TIAN J., NIE Y., ZHANG Y.E., GOLD M.S., LIU Y. Obesity: pathophysiology and intervention. Nutrients. 6 (11), 5153, 2014 
19. WANG G.J., VOLKOW N.D., LOGAN J., PAPPAS N.R., WONG C.T., ZHU W., NETUSIL N., FOWLER J.S. Brain dopamine and obesity. Lancet. 357 (9253), 354, 2001.

20. WANG G.J., VOLKOW N.D., THANOS P.K., FOWLER J.S. Imaging of brain dopamine pathways: implications for understanding obesity. J. Addict. Med. 3 (1), 8, 2009.

21. DROŻAK J., BRYŁA J. Dopamine: not just a neurotransmitter. Postepy Hig. Med. Dosw. (online). 59, 405, 2005 [In Polish].

22. GAINETDINOV R.R. Mesolimbic dopamine in obesity and diabetes. Am. J. Physiol. Regul. Integr. Comp. Physiol. 293 (2), R601, 2007

23. ALSIÖ J., OLSZEWSKI P.K., LEVINE A.S., SCHIÖTH H.B. Feed-forward mechanisms: Addiction-like behavioral and molecular adaptations in overeating. Front Neuroendocrinol. 33 (2), 127, 2012.

24. BLUM K., KOZLOWSKI G.P. Ethanol and neuromodulator interactions: a cascade model of reward. Prog. Alchohol Res. 2, 131, 1990

25. BLUM K., BRAVERMAN E.R., HOLDER J.M., LUBAR J.F., MONASTRA V.J., MILLER D., LUBAR J.O., CHEN T.J., COMINGS D.E. Reward deficiency syndrome: a biogenetic model for the diagnosis and treatment of impulsive, addictive, and compulsive behaviors. J. Psychoactive Drugs. 32 (i-iv), S1-112, 2000.

26. JORANBY L., PINEDA K.F., GOLD M.S. Addiction to food and brain reward systems. Sex. Addict Compuls. 12 (23), 201, 2005.

27. KEEN-RHINEHART E., ONDEK K., SCHNEIDER J.E. Neuroendocrine regulation of appetitive ingestive behavior. Front. Neurosci. 7, 213, 2013.

28. BLUM K., LIH-CHUAN CHEN A., BRAVERMAN E.R., COMINGS D.E., CHEN T.J.H., ARCURI V., BLUM S.H., DOWNS B.W., WAITE R.L., NOTARO A., LUBAR J., WILLIAMS L., PRIHODA T.J., PALOMO T., OSCARBERMAN M. Attention-defi cit-hyperactivity disorder and reward deficiency syndrome. Neuropsychiatr. Dis. Treat. 4 (5), 893, 2008.

29. BLUM K., OSCAR-BERMAN M., STULLER E., MILLER D., GIORDANO J., MORSE S., MCCORMICK L., DOWNS W., WAITE R.L., BARH D., NEAL D., BRAVERMAN E.R., LOHMANN R., BORSTEN J., HAUSER M., HAN D., LIU Y., HELMAN M., SIMPATICO T. Neurogenetics and nutrigenomics of neuro-nutrient therapy for reward deficiency syndrome (RDS): Clinical ramifications as a function of molecular neurobiological mechanisms. J. Addict. Res. Ther. 3 (5), 139, 2012.

30. BLUM K., FEBO M., DEMOTROVICS Z., BADGAIYAN R.D. Embracing reward deficiency syndrome (RDS) solution system: A genomic thrust. Int. Arch. Addict. Res. Med. $1(1), 2015$.

31. BLUM K, THANOS P.K., GOLD M.S. Dopamine and glucose, obesity, and reward deficiency syndrome. Front. Psychol. 5, 919, 2014.

32. DE MATOS FEIJÓ F., BERTOLUCI M.C., REIS C. Serotonin and hypothalamic control of hunger: a review. Rev. Assoc. Med. Bras. 57 (1), 74, 2011.

33. LA FLEUR S.E., SERLIE M.J. The interaction between nutrition and the brain and its consequences for body weight gain and metabolism; studies in rodents and men. Best Pract. Res. Clin. Endocrinol. Metab. 28 (5), 649, 2014.

34. ASHOR A.W., AL-GAREEB A.I. Serotonin and obesity. Mustansiriya Medical Journal. 11 (1), 99, 2012.

35. STICE E., YOKUM S., ZALD D., DAGHER A. Dopaminebased reward circuitry responsivity, genetics, and overeating. Curr. Top. Behav. Neurosci. 6, 81, 2011.
36. VUCETIC Z., KIMMEL J., TOTOKI K., HOLLENBECK E., REYES T.M. Maternal high-fat diet alters methylation and gene expression of dopamine and opioid-related genes. Endocrinology. 151 (10), 4756, 2010.

37. MADANI S., DE GIROLAMO S., MUÑOZ D.M., LI R., SWEENEY G. Direct effects of leptin on size and extracellular matrix components of human pediatric ventricular myocytes. Cardiovasc. Res. 69 (3), 716, 2006.

38. DOHERTY G.H. Obesity and the ageing brain: could leptin play a role in neurodegeneration? Curr. Gerontol. Geriatr. Res. 2011, Article ID 708154, 8 pages, 2011.

39. WIMALAWANSA S. Pathophysiology of obesity: Focused, cause-driven approach to control the epidemic. Glo. Adv. Res. J. Pharm. Pharmacol. 2 (1), 002, 2013.

40. LOH K., FUKUSHIMA A., ZHANG X., GALIC S., BRIGGS D., ENRIORI P.J., SIMONDS S., WIEDE F., REICHENBACH A., HAUSER C., SIMS N.A., BENCE K.K., ZHANG S., ZHANG Z.Y., KAHN B.B., NEEL B.G., ANDREWS Z.B., COWLEY M.A., TIGANIS T. Elevated hypothalamic TCPTP in obesity contributes to cellular leptin resistance. Cell. Metab. 14 (5), 684, 2011.

41. STASENKO S., BRADFORD E.M., PIASEK M., HENSON M.C., VARNAI V.M., JURASOVIĆ J., KUŠEC V. Metals in human placenta: focus on the effects of cadmium on steroid hormones and lepton. J. Appl. Toxicol. 30 (3), 242, 2010.

42. ATAMER Y., KOCYIGIT Y., YOKUS B., ATAMER A., ERDEN A.C. Lipid peroxidation, antioxidant defense, status of trace metals and leptin levels in preeclampsia. Eur. J. Obstet. Gynecol. Reprod. Biol. 119 (1), 60, 2005.

43. JANESICK A., BLUMBERG B. Endocrine disrupting chemicals and the developmental programming of adipogenesis and obesity. Birth. Defects. Res. C. Embryo. Today. 93 (1), 34, 2011.

44. RHIND S.M. Anthropogenic pollutants: a threat to ecosystem sustainability? Philos. Trans. R. Soc. Lond. B. Biol. Sci. 364 (1534), 3391, 2009.

45. JÄRUP L. Hazards of heavy metal contamination. Br. Med. Bull. 68, 167, 2003.

46. WHO Report. Preventing disease through healthy environments. Towards an estimate of the environmental burden of disease. (A. Prüss-Üstünand and C. Corvalán). ISBN 924159382 2, 2006.

47. GONG M., WU L., BI X.Y., REN L.M., WANG L., MAZ.D., BAO Z.Y., LI Z.G. Assessing heavy-metal contamination and sources by GIS-based approach and multivariate analysis of urban-rural top soils in Wuhan, central China. Environ. Geochem. Health. 32 (1), 59, 2010.

48. LUO X.S., YU S., ZHU Y.G., LI X.D. Trace metal contamination in urban soils of China. Sci. Total. Environ. 421-422, 17, 2012.

49. WHO Statement Lead and Cadmium: Need for International Action? IFCS/FSC/WG Lead and Cadmium/09. Prepared by The Center for International Environmental Law (CIEL) On behalf of the Government of Germany/Lead Sponsor, 2008.

50. WHO Report. Health risks of heavy metals from long-range transboundary air pollution. ISBN 978928907179 6, 2007.

51. WHO Report. Childhood Lead Poisoning. ISBN 978924 150033 3, 2010.

52. EJAZ UL I., XIAO-E Y., ZHEN-LI H., QAISAR M. Assessing potential dietary toxicity of heavy metals in selected vegetables and food crops. J. Zhejiang. Univ. SCI B. 8 (1), 1, 2007.

53. RICE D., BARONE S. Critical periods of vulnerability for the developing nervous system: evidence from humans and animal models. Environ. Health. Perspect. 108 (3), 511, 2000. 
54. PRONCZUK J., SURDUB S. Children's Environmental Health in the Twenty-First Century Challenges and Solutions. Ann. N. Y. Acad. Sci. 1140, 143, 2008.

55. AMAYA E., GIL F., FREIRE C., OLMEDO P., FERNANDEZ-RODRIGUEZ M., FERNANDEZ M.F., OLEA N. Placental concentrations of heavy metals in a mother-child cohort. Environ. Res. 120, 63, 2013.

56. FOWLER B.A. Monitoring of human populations for early markers of cadmium toxicity: a review. Toxicol. Appl. Pharmacol. 238 (3), 294, 2009.

57. ABDULLAH M.M., LY A.R., GOLDBERG W.A., CLARKE-STEWART K.A., DUDGEON J.V., MULL CH.G., CHAN T.J., KENT E.E., MASON A.Z., ERICSON J.E. Heavy metal in children's tooth enamel: Related to autism and disruptive behaviors? J. Autism. Dev. Disord. 42 (6), 929, 2012.

58. FELDMAN R.G. Occupational neurology. Yale. J. Biol. Med. 60 (2), 179, 1987.

59. FELDMAN R.G. Occupational and environmental neurotoxicology. Philadelphia, Lippincott-Raven, 1999.

60. BOUCHARD M.F., SAUVÉ S., BARBEAU B., LEGRAND M., BRODEUR M.Ė., BOUFFARD T., LIMOGES E., BELLINGER D.C., MERGLER D. Intellectual impairment in school-age children exposed to manganese from drinking water. Environ. Health. Perspect. 119 (1), 138, 2011.

61. GUILARTE T.R. Manganese and Parkinson's disease: a critical review and new findings. Environ. Health. Perspect. 118 (8), 1071, 2010

62. LANPHEAR B.P., HORNUNG R., KHOURY J., YOLTON K., BAGHURST P., BELLINGER D.C., CANFIELD R.L., DIETRICH K.N., BORNSCHEIN R., GREENE T., ROTHENBERG S.J., NEEDLEMAN H.L., SCHNAAS L., WASSERMAN G., GRAZIANO J., ROBERTS R. Low level environmental lead exposure and children's intellectual function: an international pooled analysis. Environ. Health. Perspect. 113 (7), 894, 2005.

63. TOSCANO C.D., GUILARTE T.R. Lead neurotoxicity: from exposure to molecular effects. Brain. Res. Brain. Res. Rev. 49 (3), 529, 2005.

64. NEAL A.P., GUILARTE T.R. Mechanisms of Heavy Metal Neurotoxicity: Lead and Manganese. J. Drug. Metab. Toxicol. S5:002, doi:10.4172/2157-7609.S5-002, 2012.

65. WHO Report. Children's exposure to mercury compounds. ISBN 978924150045 6, 2010

66. BERK M., KAPCZINSKI F., ANDREAZZA A.C., DEANA O.M., GIORLANDOA F., MAES M., YÜCEL M., GAMA C.S., DODDA S., DEAND B., MAGALHÃES P.V.S., AMMINGER P., MCGORRY P., MALHI G.S. Pathways underlying neuroprogression in bipolar disorder: focus on inflammation, oxidative stress and neurotrophic factors. Neurosci. Biobehav. Rev. 35 (3), 804, 2011.

67. MOYLAN S., MAES M., WRAY N.R., BERK M. The neuroprogressive nature of major depressive disorder: pathways to disease evolution and resistance, and therapeutic implications. Mol. Psychiatry. 18 (5), 595, 2013.

68. KURSULA P., MAJAVA V. A structural insight into lead neurotoxicity and calmodulin activation by heavy metals. Acta Crystallogr. Sect. F. Struct. Biol. Cryst. Commun. 63 (Pt 8), 653, 2007

69. REDDY G.R., DEVI B.C., CHETTY C.S. Developmental lead neurotoxicity: alterations in brain cholinergic system. Neurotoxicology. 28 (2), 402, 2007

70. STANLEY P.C., WAKWE V.C. Toxic trace metals in the mentally ill patients. Niger Postgrad. Med. J. 9 (4), 199, 2002.
71. WHO Report. Global health risks: mortality and burden of disease attributable to selected major risks. ISBN 978924 1563871,2009

72. LA MERRILL M., BIRNBAUM L.S. Childhood Obesity and Environmental Chemicals. Mt. Sinai. J. Med. 78 (1), 22, 2011.

73. National Obesity Observatory. Body Mass Index as a measure of obesity. Available at: www.noo.org.uk/uploads/ doc789 40 noo BMI.pdf; 2009.

74. FREEDMAN D.S., SHERRY B. The validity of BMI as an indicator of body fatness and risk among children. Pediatrics. 124 (1), S23, 2009.

75. SHAH N.R., BRAVERMAN E.R. Measuring Adiposity in Patients: The Utility of Body Mass Index (BMI), Percent Body Fat, and Leptin. PLoS ONE. 7 (4), e33308, 2012.

76. BOSE-O'REILLY S., MCCARTY K.M., STECKLING N., LETTMEIER B. Mercury Exposure and Children's Health. Curr. Probl. Pediatr. Adolesc. Health Care. 40 (8), 186, 2010

77. MODGIL S., LAHIRI D.K., SHARMA V.L., ANAND A. Role of early life exposure and environment on neurodegeneration: implications on brain disorders. Transl. Neurodegener. 3:9, doi:10.1186/2047-9158-3-9, 2014.

78. MENDEZ-ARMENTAM., RIOS C. Cadmium neurotoxicity. Environ. Toxicol. Phar. 23 (3), 350, 2007.

79. ABU-TAWEEL G.M., AJAREM J.S., AHMAD M. Protective effect of curcumin on anxiety, learning behavior, neuromuscular activities, brain neurotransmitters and oxidative stress enzymes in cadmium intoxicated mice. J. Behav. Brain. Sci. 3 (1), 74, 2013.

80. HRDINA P.D., PEETRS D.A., SINGHAL R.L. Effects of chronic exposure to cadmium, lead and mercury of brain biogenic amines in the rat. Res. Commun. Chem. Pathol. Pharmacol. 15 (3), 483, 1976.

81. ANDERSON H., PETERSEN-GREVE K., LINDQUIST J., LUTHMAN J., OSKARSSON A., OLSON L. Low-level cadmium exposure of lactating rats causes alteration of brain serotonin level in the offspring. Neurotoxicol. Teratol. 19 (2), 105, 1977.

82. CHANDRA S.V., KALIA K., HUSSAIN T. Biogenic amines and some metals in brain of cadmium-exposed diabetic rats. J. Appl. Toxicol. 5 (6), 378, 1985.

83. DAS K.P., DAS P.C., DASGUPTA S., DEY C.C. Serotoninergic-cholinergic neurotransmitters function in brain during cadmium exposure in protein restricted rat. Biol. Trace Elem. Res. 36 (2), 119, 1993.

84. NATION J.R., FRYE G.D., VON STULTZ J., BRATTON G.R. Effect of combined lead and cadmium exposure: changes in schedule-controlled responding and in dopamine, serotonin and their metabolites. Behav. Neurosci. 103 (5), $1108,1989$.

85. KAYEMBA-KAY'S S., GEARY M.P.P., PRINGLE J., RODECK CH.H., KINGDOM J.C.P., HINDMARSH P.C. Gender, smoking during pregnancy and gestational age influence cord leptin concentrations in newborn infants. Eur. J. Endocrinol. 159 (3), 217, 2008.

86. WANG G., CHEN Z., BARTELL T., WANG X. Early life origins of metabolic syndrome: The role of environmental toxicants. Curr. Environ. Health Rep. 1 (1), 78, 2014.

87. HYMAN M.A. Systems biology, toxins, obesity, and functional medicine. Altern. Ther. Health. Med. 13 (2), S134, 2007.

88. KRIMSKY S. Hormonal chaos: The scientific and social origins of the environmental endocrine hypothesis. Johns Hopkins University Press, Baltimore, USA, ISBN: 0-80186279-5, 2000. 
89. SCHUH R.A., RICHARDSON J.R., GUPTA R.K., FLAWS J.A., FISKUM G. Effects of the organochlorine pesticide methoxychlor on dopamine metabolites and transporters in the mouse brain. Neurotoxicology. 30 (2), 274, 2009.

90. BURNS J.S., WILLIAMS P.L., SERGEYEV O., KORRICK S., LEE M.M., REVICH B., ALTSHUL L., DEL PRATO J.T., HUMBLET O., PATTERSON JR D.G., TURNER W.E., NEEDHAM L.L., STAROVOYTOV M., HAUSER R. Serum dioxins and polychlorinated biphenyls are associated with growth among Russian boys. Pediatrics. 127 (1), e5968, 2011.

91. VALVI D., MENDEZ M.A., MARTINEZ D., GRIMALT J.O., TORRENT M., SUNYER J., VRIJHEID M. Prenatal concentrations of polychlorinated biphenyls, DDE, and DDT and overweight in children: a prospective birth cohort study. Environ. Health. Perspect. 120 (3), 451, 2012.

92. CUPUL-UICAB L.A., KLEBANOFF M.A., BROCK J.W., LONGNECKER M.P. Prenatal exposure to persistent organochlorines and childhood obesity in the U.S. collaborative perinatal project. Environ. Health. Perspect. 121 (9), 1103, 2013.

93. WARNER M., SCHALL R.A., HARLEY K.G., BRADMAN A., BARR D., ESKENAZI B. In Utero DDT and DDE Exposure and Obesity Status of 7-Year-Old MexicanAmerican Children in the CHAMACOS Cohort. Environ. Health. Perspect. 121 (5), 631, 2013.

94. ARREBOLA J.P., OCANA-RIOLA R., ARREBOLAMORENO A.L., FERNANDEZ-RODRÍGUEZ M., MARTIN-OLMEDO P., FERNANDEZ M.F., OLEA N. Associations of accumulated exposure to persistent organic pollutants with serum lipids and obesity in an adult cohort from Southern Spain. Environ. Pollut. 195, 9, 2014.

95. DELVAUX I., VAN CAUWENBERGHE J., HOND E.D., SCHOETERS G., GOVARTS E., NELEN V., BAEYENS W., VAN LAREBEKE N., SIOEN I. Prenatal exposure to environmental contaminants and body composition at age 7-9 years. Environ. Res. 132, 24, 2014.

96. HØYER B.B., RAMLAU-HANSEN C.H., HENRIKSEN T.B., PEDERSEN H.S., GÓRALCZYK K., ZVIEZDAI V., JÖNSSON B.A.G., HEEDERIK D., LENTERS V., VERMEULEN R., BONDE J.P., TOFT G. Body mass index in young school-age children in relation to organochlorine compounds in early life: a prospective study. Int. J. Obes. 38 (7), 919, 2014

97. TANG-PE'RONARD J.L., HEITMANN B.L., ANDERSEN H.R., STEUERWALD U., GRANDJEAN P., WEIHE P., JENSEN T.K. Association between prenatal polychlorinated biphenyl exposure and obesity development at ages 5 and $7 \mathrm{y}$ : a prospective cohort study of 656 children from the Faroe Islands. Am. J. Clin. Nutr. 99 (1), 5, 2014.

98. DURCZOK A., SZKILNIK R., NOWAK P., LABUS Ł., DĄBROWSKA J., BORTEL A., ZAGZIŁ T., SWOBODA M., RYCERSKI W., WINNICKA H., KOSTRZEWA R.M., KWIECIŃSKI A., BRUS R. The effects of zinc on the central dopaminergic system of rats prenatally exposed to cadmium. Pol. J. Environ. Stud. 14 (5), 569, 2005.

99. MOOS T., MORGAN E.H. The metabolism of neuronal iron and its pathogenic role in neurological disease: Review. Ann. N. Y. Acad. Sci. 1012, 14, 2004.

100. EL-BAKY A.E.A. The role of curcuminoids in overcoming neurodegenerative disorders resulting from heavy metal overload. International JBPR. 1 (3), 110, 2012.

101. VELEZ-PARDO C., JIMENEZ DEL RIO M., VERSCHUEREN H., EBINGER G., VANQUELIN G. Dopamine and iron induce apoptosis in PC12 cells. Pharmacol.
Toxicol. 80 (2), 76, 1997.

102. AIRAKSINEN R., RANTAKOKKO P., ERIKSSON J.G., BLOMSTEDT P., KAJANTIE E., KIVIRANTA H. Association between type 2 diabetes and exposure to persistent organic pollutants. Diabetes Care. 34 (9), 1972, 2011.

103. FERGUSON K.K., O’NEILL M.S., MEEKER J.D. Environmental contaminant exposures and preterm birth: A comprehensive review. J. Toxicol. Environ. Health. B: Criti. Rev. 16 (2), 69, 2013.

104. BLOCKER T.D., OPHIR A.G. Cryptic confounding compounds: A brief consideration of the influences of anthropogenic contaminants on courtship and mating behavior. Acta Ethol. 16 (2), 105, 2013.

105. HATCHER J.M., DELEA K.C., RICHARDSON J.R., PENNELL K.D., MILLER G.W. Disruption of dopamine transport by DDT and its metabolites. NeuroToxicology. 29 (4), 682, 2008.

106. KLAASSEN C.D., editor. Casarett \& Doull's toxicology: the basic science of poisons. New York, McGraw-Hill, 2001.

107. HEINDEL J.J. Endocrine disruptors and the obesity epidemic. Toxicol. Sci. 76 (2), 247, 2003.

108. NEWBOLD R.R., PADILLA-BANKS E., JEFFERSON W.N., HEINDEL J.J. Effects of endocrine disruptors on obesity. Int. J. Androl. 31 (2), 201, 2008.

109. EMOND C., BIRNBAUM L.S., DEVITO M.J. Use of a physiologically based pharmacokinetic model for rats to study the influence of body fat mass and induction of CYP1A2 on the pharmacokinetics of TCDD. Environ. Health. Perspect. 114 (9), 1394, 2006.

110. LONGNECKER M.P. Pharmacokinetic variability and the miracle of modern analytical chemistry. Epidemiology. 17 (4), 350, 2006

111. JONES O.A., MAGUIRE M.L., GRIFFI J.L. Environmental pollution and diabetes: a neglected association. Lancet. 371 (9609), 287, 2008.

112. HUMBLET O., BIRNBAUM L., RIMM E., MITTLEMAN M.A., HAUSER R. Dioxins and cardiovascular disease mortality. Environ. Health. Perspect. 116 (11), 1443, 2008.

113. YAMAGISHI S.I., EDELSTEIN D., DU X.L., KANEDA Y., GUZMAN M., BROWNLEE M. Leptin induces mitochondrial superoxide production and monocyte chemoattractant protein-1 expression in aortic endothelial cells by increasing fatty acid oxidation via protein kinase A. J. Biol. Chem. 276 (27), 25096, 2001.

114. MARIUSSEN E., FONNUM F. Neurochemical targets and behavioral effects of organohalogen compounds: an update. Crit. Rev. Toxicol. 36 (3), 253, 2006.

115. BLOOMQUIST J.R., BARLOW R.L., GILLETTE J.S., LI W., KIRBY M.L. Selective effects of insecticides on nigrostriatal dopaminergic nerve pathways. Neurotoxicology. 23 (4), 537, 2002.

116. DEICHMANN W.B., MACDONALD W.E., CUBIT D.A., BEASLEY A.G. Effects of starvation in rats with elevated DDT and dieldrin tissue levels. Internationales Archiv für Arbeitsmedizin. 9 (3), 233, 1972.

117. VILLENEUVE D.C., VAN LOGTEN M.J., DEN TONKELAAR E.M., GREVE P.A., VOS J.G., SPEIJERS G.J., VAN ESCH G.J. Effect of food deprivation on low level hexachlorobenzene exposure in rats. Sci. Total. Environ. 8 (2), 179, 1977.

118. LIM S., AHN S.Y., SONG I.C., CHUNG M.H., JANG H.C., PARK K.S., LEE K.U., PARK Y.K., LEE H.K. Chronic exposure to the herbicide, atrazine, causes mitochondrial dysfunction and insulin resistance. PLoS One. 4 (4), e5186, 2009. 
119. RUZZIN J., PETERSEN R., MEUGNIER E., MADSEN L., LOCK E.J., LILLEFOSSE H., MA T., PESENTI S., SONNE S.B., MARSTRAND T.T., MALDE M.K., DU Z.Y., CHAVEY C., FAJAS L., LUNDEBYE A.K., BRAND C.L., VIDAL H., KRISTIANSEN K., FRØYLAND L. Persistent organic pollutant exposure leads to insulin resistance syndrome. Environ. Health. Perspect. 118 (4), 465, 2010.

120. HATCH E.E., NELSON J.W., STAHLHUT R.W., WEBSTER T.F. Association of endocrine disruptors and obesity: perspectives from epidemiological studies. Int. J. Androl. 33 (2), 324, 2010

121. RÖNN M. Environmental contaminants and obesity. Acta Universitatis Upsaliensis. Uppsala, ISBN 978-91-5548798-0, 2013.

122. PROVOST T., KENNEDY M., CASTRACANE V.D., LEE A.M. The effects of polychlorinated biphenyl on circulating leptin and thyroid hormone status in Sprague -Dawley rats, Rattus norvegicus. Ohio J. Sci. 107 (2), 19, 2007.

123. ROCHESTER J.R. Bisphenol A and human health: A review of the literature. Reprod. Toxicol. 42, 132, 2013.

124. VANDENBERG L.N., EHRLICH S., BELCHER S.M., BEN-JONATHAN N., DOLINOY D.C., EHRLICH S. LOW dose effects of bisphenol A: An integrated review of in vitro, laboratory animal and epidemiology studies. Endocrine Disruption. 1 (1), e25078-1-e25078-20, 2013.

125. VOM SAAL F.S., WELSHONS W.V. Evidence that bisphenol A (BPA) can be accurately measured without contamination in human serum and urine, and that BPA causes numerous hazards from multiple routes of exposure. Mol. Cell. Endocrinol. 398 (1-2), 101-113, 2014.

126. TAXVIG C., DREISIG K., BOBERG J., NELLEMANN C., SCHELDE A.B., PEDERSEN D., BOERGESEN M., MANDRUP S., VINGGAARD A.M. Differential effects of environmental chemicals and food contaminants on adipogenesis, biomarker release and PPAR $\gamma$ activation. Mol. Cell. Endocrinol. 361 (1-2), 106, 2012.

127. ARSENESCU V., ARSENESCU R.I., KING V., SWANSON H., CASSIS L.A. Polychlorinated biphenyl-77 induces adipocyte differentiation and proinflammatory adipokines and promotes obesity and atherosclerosis. Environ. Health. Perspect. 116 (6), 761, 2008.

128. HENNIG B., ORMSBEE L., MCCLAIN C.J., WATKINS B.A., BLUMBERG B., BACHAS L.G., SANDERSON W., THOMPSON C., SUK W.A. Nutrition can modulate the toxicity of environmental pollutants: Implications in risk assessment and human health. Environ. Health. Perspect. 120 (6), 771, 2012.
129. BASHANDY S.A., ALHAZZA I.M. The hepatoprotective effect of $\beta$-carotene against cadmium toxicity in rats. J. Pharmacol. Toxicol. 3 (6), 457, 2008.

130. AL-ATTAR A.M. Vitamin E attenuates liver injury induced by exposure to lead, mercury, cadmium and copper in albino mice. Saudi. J. Biol. Sci. 18 (4), 395, 2011

131. POLJŠAK B., FINK R. The protective role of antioxidants in the defence against ROS/RNS-mediated environmental pollution. Oxid. Med. Cell. Longev. 2014, 671539, 2014.

132. EL-BOSHY M.E., RISHA E.F., ABDELHAMID F.M., MUBARAK M.S., HADDA T.B. Protective effects of selenium against cadmium induced hematological disturbances, immunosuppressive, oxidative stress and hepatorenal damage in rats. J. Trace Elem. Med. Biol. 29, 104, 2014.

133. TAI C.C., DING S.T. N-3 polyunsaturated fatty acids regulate lipid metabolism through several inflammation mediators: mechanisms and implications for obesity prevention. J. Nutr. Biochem. 21 (5), 357, 2010.

134. KIM J., LI Y., WATKINS B.A. Endocannabinoid signaling and energy metabolism: a target for dietary intervention. Nutrition. 27 (6), 624, 2011

135. VAN ELST V., BRUININGA H., BIRTOLI B., TERREAUXC C., BUITELAARD J.K., KAS M.J. Food for thought: Dietary changes in essential fatty acid ratios and the increase in autism spectrum disorders. Neurosci. Biobehav. Rev. 45, 369-378, 2014.

136. HONG M.Y., LUMIBAO J., MISTRY P., SALEH R., HOH E. Fish oil contaminated with persistent organic pollutants reduces antioxidant capacity and induces oxidative stress without affecting its capacity to lower lipid concentrations and systemic inflammation in rats. J. Nutr. 145 (5), 2015.

137. SMINK A., RIBAS-FITO N., GARCIA R., TORRENT M., MENDEZ M.A., GRIMALT J.O., SUNYER J. Exposure to hexachlorobenzene during pregnancy increases the risk of overweight in children aged 6 years. Acta Paediatr. 97 (10), $1465,2008$.

138. THIRUCHELVAM M., RICHFIELD E.K., GOODMAN B.M., BAGGS R.B., CORY-SLECHTA D.A. Development exposure to the pesticides paraquat and maneb and the Parkinson's disease phenotype. Neurotoxicology. 23 (4-5), 621, 2002.

139. WHO Statement. Early life opportunities for the prevention of non-communicable disease in developing countries. 2011.

140. HUE O., MARCOTTE J., BERRIGAN F., SIMONEAU M., DORÉ J., MARCEAU P., MARCEAU S., TREMBLAY A., TEASDALE N. Increased plasma levels of toxic pollutants accompanying weight loss induced by hypocaloric diet or by bariatric surgery. Obes. Surg. 16 (9), 1145, 2006. 